\author{
Barbara Riman \\ Inštitut za narodnostna vprašanja \\ Erjavčeva c. 26, SI-1000 Ljubljana \\ barbara.riman@guest.arnes.si
}

\title{
Čitaonicu je osnovala „šaka braće Slovenacah" u želji „da pokažu svietu, da se znadu ponosit svojim dičnim imenom, svojim milim jezikom": slovenska društva u Puli od 1886. do 2011. godine
}

Prethodno priopćenje | Preliminary communication UDK 061.237(497.5 Pula=163.6)«198/20«

Primljeno | Received: 27. VIII. 2012.

\begin{abstract}
Izvadak
Postojanje slovenskih društava na prostoru današnje Republike Hrvatske bilježi se od kraja 19. stoljeća. U nekim gradovima, gdje je broj stanovnika koji su se doselili iz slovenskih krajeva bio stalan, slovenska društva s većim ili manjim pauzama u djelovanju postoje već skoro stoljeće i pol. Prvo slovensko društvo u Puli bilo je osnovano 1886. godine. Korištenjem različite metodologije istraživanja donosi se prikaz osnivanja i djelovanja slovenskih društava u Puli od 80-ih godina 19. stoljeća do današnjih dana. Kroz povijest su slovenska društva mijenjala svoju dimenziju. U početku su ona bila u prvom redu mjesto gdje su doseljenici i pridošlice tražili potporu i sigurnost. Uz tu egzistencijalnu, društva su imala i kulturnu dimenziju, koja je prevladala. Današnja slovenska društva na prostoru Republike Hrvatske, pa tako i Slovensko kulturno društvo „Istra” u Puli koje djeluje od 2001., svoje djelovanje temelje na različitim aktivnostima kojima nastoje očuvati jezik i kulturu koju su naslijedili od svojih predaka. Potrebno je naglasiti da na taj način djeluju i u smjeru očuvanja i jačanja dobrosusjedskih odnosa.
\end{abstract}

\section{Abstract}

The existence of Slovenian societies in what is today Republic of Croatia can be dated back to the end of $19^{\text {th }}$ century. In some cities, where the number of the 
people who had settled from Slovenia was constant, Slovenian societies exist, with some breaks, for a century and a half. First Slovenian society of Pula was founded in 1886. By using different research techniques, the founding and the activities of Slovenian societies of Pula in the period between 1880's and contemporary times, have been shown. Throughout history, Slovenian societies have changed their dimension. At the beginning, they were a place where settlers and newcomers could find support and security. Alongside that existential dimension, societies had a cultural role, the prevailing one. Contemporary Slovenian societies which exist in Republic of Croatia, including "Istra" - Slovenian cultural society founded in 2001, base their work on different activities which help them to preserve the language and culture they have inherited from their ancestors. It should be emphasized that by doing that, they preserve and strengthen the neighbourly relations.

Ključne riječi: Istra, Pula, samoorganizacija, nacionalne manjine, društva nacionalnih manjina, slovenska nacionalna manjina, slovenska društva u Puli

Key words: Istria, Pula, self-organizing, minorities, minority societies, Slovenian minority, Slovenian societies of Pula

\section{O samoorganizaciji}

Povijest čovječanstva od samih je početaka zapravo povijest migracija. Tako je i povijest europskoga kontinenta usko povezana s migracijama i seljenjem stanovništva. ${ }^{1}$ Te brojne migracije utjecale su i na povijest današnjega hrvatskog prostora, a pogotovo su bile vidljive u vremenima velikih političkih i povijesnih promjena. Među došljacima na današnji prostor Republike Hrvatske zabilježeni su i oni stanovnici koji su došli iz različitih slovenskih krajeva. Oni su se, kao i drugi doseljenici, uključivali u svakodnevicu i utjecali su na suoblikovanje kulture u koju su došli prihvativši norme ponašanja koje su zatekli na prostorima na koje su se doselili.

Kada se na određenom prostoru stabilizira određena skupina doseljenih obitelji i pojedinaca, često se takva društvena skupina i organizira. Dovoljno velik broj doseljenika je ujedno i prvi uvjet da bi se društvo osnovalo. ${ }^{2}$ Posljedica njihovoga stalnog naseljavanja na određenom prostoru su

1 Smatra se da homo migrans postoji od kada postoji i homo sapiens te da je seljenje dio ljudske egzistencije kao i rođenje, razmnožavanje, bolest i smrt. Migracije su kao društveni procesi, osim izgona i bijega, odaziv na više ili manje kompleksne ekonomske i ekološke, socijalne i kulturne, egzistencijalne i društvene odnose. Više o tome u: Klaus Bade, Evropa v gibanju, Ljubljana 2005., 8-9; Matjaž Klemenčič, „Migrations in history“, Immigration and emigration in historical perspective, ur. Ann Katherine Isaacs, Pisa $2007 ., 28$.

2 Vera Kržišnik-Bukić, „O narodnostnem in kulturnem samoorganiziranju Slovencev na Hrvaškem v 20. stoletju“ (dalje: „O narodnostnem in kulturnem samoorganiziranju Slovencev“), Slovenci v Hrvaški, ur. Vera Kržišnik-Bukić, Ljubljana 1995., 133-134. 
trajniji oblici udruživanja. Društva koja su doseljenici osnovali imala su različite zadaće. Ovisno o tome, možemo govoriti o trima dimenzijama tih društava. Prva je egzistencijalna, druga je kulturna, a treća je politička.

Egzistencijalna dimenzija je bila potporna, odnosno, u društvima se često prikupljala financijska pomoć za bolesne i ozlijeđene članove ili za obitelji koje su ostale bez hranitelja. Tako su si, ali i na druge načine, međusobno pomagali kako bi se lakše snašli u tuđem kraju. Zabilježeno je da su neka društva organizirala tečajeve za svoje članove, a radi lakšega zapošljavanja. U pravilima nekih društava je kao primarni cilj bilo zabilježeno da je društvo osnovano upravo radi pomoći onima koji su se doselili u određeni kraj da bi lakše našli posao ili smještaj. ${ }^{3}$ Osim tih egzistencijalnih razloga, često su osnovana društva imala i kulturnu dimenziju, odnosno ulogu nositelja kulturnoga, obrazovnoga i društvenoga života doseljenika. Društva s primarnom kulturnom dimenzijom imala su različita usmjerenja; od kulturno-prosvjetnih do sportskih. Osnivani su pjevački zborovi, tamburaški ili harmonikaški orkestri i limene glazbe. Pokretačka sila tih udruga su uglavnom bili učitelji, svećenici i studenti. Zabilježeno je i da su brojna društva imala svoje knjižnice ili su ih nastojala osnovati, a neka od njih su tiskala i svoja glasila. ${ }^{4}$

Često su članovi kroz društva jasno izražavali i politička mišljenja, čime društvo dobiva i političku dimenziju, no na hrvatskim prostorima nije bila zabilježena ta politička dimenzija.

Kada se govori o samoorganizaciji etnički manjinskoga dijela stanovništva, to osnivanje i djelovanje društava ima vrlo važnu ulogu kao vanjski pokazatelj postojanja neke manjine u većinskom nacionalnom okruženju. Poznavanje organiziranosti pojedine nacionalne skupine važan je izvor za istraživanje i sustavno sakupljanje podataka o toj skupini. ${ }^{5}$

3 Kao primjer može se navesti Slovensko izobraževalno in humanistično društvo „Simon Gregorčič“ koje je djelovalo na Sušaku od 1927. pa do početka Drugoga svjetskog rata. O ciljevima njegova rada zabilježeno je bilo sljedeće: „Ovih su dana braća Slovenci osnovali u Sušaku svoje društvo sa imenom »Simon Gregorčič«. Zadatak ovog društva je, da upoznava ovdašnje pučanstvo sa kulturnim tekovinama slovenskog dijela našeg jugoslovenskog naroda. (...) Društvo ima i jedan drugi vrlo važan zadatak, a to je: informiranje onih sunarodnjaka koji bi htjeli da se nasele u Sušak ili gdje drugdje u Primorje.“ „Slovensko izobraževalno društvo »Simon Gregorčič巛 u Sušaku“, Novi list, 14. 12. 1927., 4.

4 Da bi društvo tiskalo glasilo bilo je potrebno ispuniti nekoliko uvjeta. Tiskanje vlastita glasila je predstavljalo, a još i danas predstavlja, jedan od najvažnijih izazova u životu neke manjinske etničke skupine. Ona je morala biti „puna života“ i u njoj se moralo stalno nešto događati o čemu bi bilo vrijedno pisati. Na nastanak glasila utjecala je i struktura članstva, odnosno stupanj obrazovanja i tehničkih mogućnosti. Matjaž Klemenčič, ,,Slovenske naselbine v ZDA“, Slovensko izseljenstvo. Zbornik ob 50-letnici Slovenske izseljenske matice, ur. Milica Trebše-Štolfa, Ljubljana 2001., 184.

5 Kržišnik-Bukić, „O narodnostnem in kulturnem samoorganiziranju Slovencev“, 133-134. 
Samoorganiziranje slovenskoga etničkog elementa u društva na prostoru Republike Hrvatske, pa tako i u Puli, potrebno je promatrati s više različitih gledišta. U prvom se redu može promatrati kronološki, kao i u odnosu na sadržaje njihova rada. Naime, bez jasnoga kronološkog slijeda nije moguće pratiti razvitak određenoga društva, dok je proučavanje sadržaja rada društva prijeko potrebno želi li se ustanoviti značaj i važnost društva i pojedinih njegovih članova za lokalnu zajednicu te, eventualno, i širu društvenu zajednicu u kojoj određena nacionalna manjina živi i djeluje. Temi je moguće pristupiti na najneposredniji način, i to praćenjem djelovanja konkretnih društava na današnjem prostoru Republike Hrvatske od njihova osnivanja do prestanka postojanja. U istraživanje djelovanja nekoga društva svakako valja uključiti biografije njegovih članova, kao i sjećanja pojedinih članova društva. Nažalost, zbog velikoga vremenskog odmaka često to nije moguće i stoga se gubi važan izvor podataka za prikaz djelovanja određenoga društva. Pri istraživanju je potrebno razmatrati vrijeme nastanka i djelovanja društva s obzirom na društvene i političke povijesne okolnosti. Do sada je bila uvriježena, pri istraživanju povijesti slovenskih društava u Hrvatskoj, sljedeća periodizacija: razdoblje između dva svjetska rata, vrijeme Drugoga svjetskog rata, drugo jugoslavensko razdoblje te razdoblje djelovanja društava u samostalnoj državi Hrvatskoj. ${ }^{6} \mathrm{U}$ tu periodizaciju bilo bi potrebno uključiti i razdoblje prije Prvoga svjetskog rata. Novija su istraživanja pokazala da je aktivnost slovenskih udruženja od kraja 19. stoljeća do 1914. na prostoru Kvarnera i Istre bila vrlo jaka i raznolika.

Arhivsko je gradivo društava sačuvano samo djelomično, što utječe na rekonstrukciju osnivanja i djelovanja određenoga društva. Stoga je nemoguće cjelovito predstaviti članstvo pojedinoga društva, neovisno o vremenu u kojem je djelovalo. Mnogo se podataka o djelovanju društva može dobiti iz časopisa koji su bili tiskani u vrijeme kada je društvo postojalo. U tiskanim medijima objavljivani su različiti napisi koji su prikazivali djelovanje društava, a danas su to često i jedini izvori podataka o društvu i njegovim članovima. ${ }^{7}$

Do sada se o samoorganiziranosti i društvenoj djelatnosti stanovništva doseljenoga na prostor Hrvatske pisalo relativno malo, a to se odnosi

6 Idem, 145.

$7 \quad$ U radu su svi napisi klasificirani jednako i nisu podijeljeni na kritike, osvrte, vijesti i obavijesti jer imaju samo informacijsku funkciju. 
i na stanovništvo doseljeno u Pulu i okolicu. Stoga se pri istraživanju tih procesa otvaraju mnoga pitanja.

U nastavku rada prikazat će se djelovanje slovenskih društava u Puli od kraja 19. do početka 21. stoljeća. Za potrebe rada korištena je historiografska metoda, metode analize, komparacije, sinteze i generalizacije. Ove metode omogućile su odgovore na niz pitanja. Činilo se važnim ustanoviti jesu li društva osnivali, kao i u drugim mjestima, intelektualci i studenti ili je poticaj dolazio iz nekoga drugog izvora. Također je važno saznati koliko su na ta društva utjecala društvena i politička događanja te koliko su sama društva utjecala na život u sredini gdje su djelovala, u ovom slučaju u Puli. Važnim se čini razmotriti jesu li društva imala ciljeve kao i druga slovenska društva na prostoru današnje Republike Hrvatske u određenom vremenu ili su ona funkcionirala drugačije, uvjetovana regijom gdje su postojala. Potrebno bi bilo usporediti djelovanje društva slovenskih doseljenika s kraja 19. i početka 20. stoljeća s djelovanjem društva u Istri u 21. stoljeću.

Nastajanje i djelovanje slovenskih društava na prostoru današnje Hrvatske, pa tako i u Puli, u literaturi se uglavnom spominje tek usputno. Podaci o njihovom postojanju i radu susreću se u knjizi Janeza Kramara Narodna prebuja istrskih Slovencev, ${ }^{8}$ gdje se navode slovenska društva koja su u Puli djelovala na početku 20. stoljeća. Ta društva spominje i Vera Kržišnik-Bukić u svojem članku „O narodnostnem in kulturnem samoorganiziranju Slovencev na Hrvaškem v 20. stoletju“. ${ }^{9}$ U njemu donosi teorijske postavke o samoorganizaciji, kao i pregled slovenskih društava u 20. stoljeću na prostoru današnje Republike Hrvatske. Postojanje slovenskih društava na početku 20. stoljeća u Puli spominje i Vitomir Ujčić. ${ }^{10}$ O slovenskim društvima te o aktivnosti doseljenoga slovenskog stanovništva, posebno nakon 1991., u svojim radovima prikazuje Karmen Medica. ${ }^{11}$

Samoorganiziranje slovenskih doseljenika može se pratiti na cijelom prostoru današnje Hrvatske. Do 1991. zabilježeno je postojanje više od 30

8 Janez Kramar, Narodna prebuja istrskih Slovencev, Trst 1991.

9 Vidi bilj. 2.

10 Vitomir Ujčić, Kazališni i kulturno-umjetnički život Pule, Pula 1962., 30.

11 Karmen Medica, „Sodobno organizacijsko povezovanje Slovencev v hrvaški Istri“, Slovenci v Hrvaški, 391-400; eadem, „Perspektive slovenske manjšine v hrvaški Istri skozi kulturne dejavnosti“, Slovenci na Hrvaškem - dedǐ̌čina in sedanjost, zbornik referatov s posveta Etnološka dediščina in kulturna podoba Slovencev na Hrvaškem, ur. Katalin Munda Hirnök in Mojca Ravnik, Knjižnica Glasnika Slovenskega etnološkega društva 39, Ljubljana 2006., 127-136; eadem, „»Slovensko kulturno društvo Istra« v Pulju“, Annales, 15, 1, 2005., 207-208. 
slovenskih društava koja su djelovala u različitim povijesnim razdobljima i različitim intenzitetom, uglavnom u većim gradovima koji su bili u neposrednoj blizini hrvatsko-slovenske granice ili u industrijskim centrima, gdje je kroz povijest bilo jačeg i brojnijeg doseljavanja. Tako su slovenska društva prije 1991., osim u Puli, postojala u Zagrebu, Karlovcu, Rijeci, Osijeku i Opatiji. U ostalim je mjestima osnivanje društava zabilježeno nakon 1991., odnosno nakon što su obje države postale neovisne, a skrb za Slovence na prostoru današnje Republike Hrvatske se povećala. ${ }^{12}$

\section{O Puli}

Pula je grad koji ima vrlo složene uvjete za život. Geografski gledano, njezin smještaj u prostoru šire regije vrlo je pogodan za razvoj grada, ali su s time u suprotnosti krajnje nepovoljni klimatski uvjeti i hidrološki resursi. Grad se, stoga, kroz pojedina povijesna razdoblja razvijao do impozantnih razmjera, ali je, također, zapadao u teške gospodarske i demografske krize za kojih je jedva sačuvao urbani status.

Promjene koje su se odigravale kroz povijest grada nerijetko su bivale dramatične. Zabilježeni su brojni poduhvati revitalizacije grada i naseljavanja novoga stanovništva koje je dolazilo je iz Dalmacije, Albanije i Grčke, ali to je vrlo slabo utjecalo na zaustavljanje propadanja grada u 17 . stoljeću. ${ }^{13}$ U 18. stoljeću grad je imao samo 1000 stanovnika, ${ }^{14}$ a preduvjeti za njegov procvat dogodili su se nakon pada Mletačke Republike 1797., kada je Pula ušla u granice Habsburške Monarhije. Grad je tada bio tek tranzitno mjesto koje, zbog nezdrave klime, nije bilo perspektivno. Od demografskih gubitaka nakon brojnih epidemija kuge, malarije, velikih boginja i drugih bolesti, Pula se neće oporaviti sve do druge polovice 19. stoljeća. ${ }^{15}$ Tada mjesto postaje važno ekonomsko, gospodarsko, vojno i kulturno središte, i to stoga što su ga vojne vlasti odredile za glavnu ratnu luku Austro-Ugarske Monar-

12 Od 1991. do danas su na prostoru Republike Hrvatske osnovana sljedeća društva: Slovensko kulturno društvo „Triglav“ u Splitu, Društvo Slovenaca „Dr. France Prešeren“ u Šibeniku, Slovensko kulturno društvo „Lipa“ u Dubrovniku, Slovensko kulturno društvo „Lipa“ u Zadru, Slovensko kulturno društvo „Istra“ u Puli, Slovensko kulturno umetniško društvo „Snežnik“ u Lovranu, Društvo Slovenaca „Labin“ u Labinu, Kulturno društvo Slovenski dom Karlovac u Karlovcu, Slovensko kulturno društvo „Stanko Vraz“ u Osijeku, Slovensko kulturno društvo „Oljka“ u Poreču, Slovensko kulturno društvo „Lipa“ u Buzetu, Slovensko društvo „Nagelj“ u Varaždinu, Slovensko kulturno društvo „Gorski kotar“ u Čabru i Slovensko kulturno društvo „Ajda“ u Umagu.

13 Miroslav Bertoša, „Hajdučka epizoda naseljivanja Puljštine (1671-1675)“, Jadranski zbornik, VIII, 1973. 105-158.

14 Robert Matijašić, „Pula“, Istarska enciklopedija, ur. Miroslav Bertoša i Robert Matijašić, Zagreb 2005., 655659.

15 Darko Dukovski, Istra: kratka povijest dugoga trajanja, Pula 2004., 80. 
hije. ${ }^{16}$ Nakon te su odluke vlasti krenule s gradnjom Pomorskoga arsenala južno od starogradske jezgre. Prateći vojni objekti i velike vojarne zauzeli su brojna mjesta u gradu te gotovo cjelokupnu obalu Pulskoga zaljeva, a oko grada izgrađen je sustav utvrda za obranu s kopna i mora u sustavu dvaju prstena. ${ }^{17}$ Pula je 1867. dobila željezničku prugu i tako je grad povezan s europskom željezničkom mrežom.

Grad je do 1914. potpuno izmijenio svoj izgled, mjesto je postalo kozmopolitskim gradom koji je privlačio radnu snagu iz okolice i južne Istre, ali i specijaliste (inženjere, vojno osoblje, slobodna zanimanja, učitelje i dr.) potrebne mornarici, i to iz svih dijelova Monarhije. U uporabi su bili talijanski, hrvatski i njemački jezik, ali se govorilo i mađarskim, češkim, slovenskim i drugim jezicima. U političkom životu glavnu je riječ imalo talijansko građanstvo, koje se borilo za prevlast s njemačkim vojnim vlastima i hrvatskim/slavenskim stanovništvom prigrada i šire okolice. ${ }^{18}$

Nagli razvitak grada utjecao je i na povećanje broja stanovnika. Malo je gradova zabilježilo tako nagli rast populacije kao Pula od druge četvrtine 19. stoljeća. Godine 1811. u Puli je bilo 812 stanovnika, 1818. 926, ${ }^{19} 1842$. $1.126,{ }^{20}$ a već 1847 . je u Puli bio 8.551 stanovnik, od čega oko 2000 vojnih osoba. Dvadeset godina poslije (1867.) Pula je brojila 17.303 stanovnika. ${ }^{21}$

Iz postojećih popisa stanovništva vidljivo je koliko se u Puli od 1880. do 1910. povećao broj ljudi, a vidljiva je i promjena u nacionalnoj strukturi stanovništva. ${ }^{22}$

16 Darko Darovec, Kratka zgodovina Istre, Založba Annales, Koper 2008., 185.

17 Miroslav Bertoša, „Usponi i sutoni“, Pula: tri tisućljeća mita i stvarnosti, ur. Elmo Cvek, Pula 2005., 92.

18 Matijašić, „Pula“, 655-659.

19 Bertoša, „Usponi i sutoni“, 89.

20 Idem, 92.

21 Od toga su zabilježene 4.303 vojne osobe (idem, 93; Tone Peruško, „Historijat »Uljanika« do 1947. godine“, Pomorski zbornik, 2, 1964., 396). U Puli je skoro svaki četvrti stanovnik bio vojnik koji je u grad došao po službenoj dužnosti. Potrebno je spomenuti i nacionalnu strukturu posade na ratnim brodovima Austro-Ugarske Monarhije. U 1910. godini mornaricu je činilo 29,8\% Hrvata, 24,5 \% Nijemaca i Austrijanaca, 12,6 \% Mađara, 18,3 \% Talijana, 7,1 \% Čeha i Slovaka, 3,6 \% Slovenaca i 1 \% Poljaka. Dieter Winkler, „Pula kao glavna ratna luka Monarhije“, Carska i kraljevska mornarica u Puli, katalog izložbe, ur. Bruno Dobrić, Pula 1999., 5.

22 Detaljan prikaz etničke strukture stanovništva u vrijeme Austro-Ugarske Monarhije, kao i u vremenu između dva svjetska rata te nakon Drugoga svjetskog rata dali su Matjaž Klemenčič - Vladimir Klemenčič, Die Kärntner Slowenen und die Zweite Republik: zwischen Assimilierungsdruck und dem Einsatz für die Umsetzung der Minderheitenrechte, Klagenfurt - Ljubljana - Beč 2010., 108-109. 


\begin{tabular}{|c|c|c|c|c|c|c|}
\hline \multirow{2}{*}{$\begin{array}{c}\text { Godina } \\
\text { popisa }\end{array}$} & \multicolumn{5}{|c|}{ Pula - sastav stanovništva po nacionalnosti (uporabnom jeziku) } \\
\cline { 2 - 7 } & Ukupno & hrvatski & slovenski & njemački & talijanski & ostali \\
\hline 1880. & 25.173 & 3.675 & 1.283 & 3.826 & 11.503 & 298 \\
\hline 1890. & 31.623 & 4.968 & 1.480 & 4.400 & 16.399 & 404 \\
\hline 1900. & 36.227 & 4.820 & 1.514 & 4.543 & 20.947 & 398 \\
\hline 1910. & 58.562 & 9.511 & 3.293 & 9.064 & 26.812 & 9.858 \\
\hline
\end{tabular}

Tablica 1: Popis stanovnika Pule prema uporabnom jeziku od 1880. do 1991. godine ${ }^{23}$

Kao što je vidljivo iz tablice, broj se žitelja Pule krajem 19. i početkom 20. stoljeća vrlo brzo mijenjao; od 1880. do 1910. se čak udvostručio. Sukladno tim brojkama, povećavao se ili relativno smanjivao broj pripadnika različitih naroda koji su već tradicionalno bili prisutni u Puli. Od 1900. do 1910. udvostručio se broj govornika slovenskoga jezika, kao i broj govornika hrvatskoga i njemačkoga jezika. Tako nagli rast možemo objasniti odgovarajućim gospodarskim i demografskim razvitkom Pule. ${ }^{24}$

U ustroju života grada, tj. njegova urbaniteta, od kraja 19. stoljeća je bilo zabilježeno djelovanje većega broja različitih društava. To nije bilo karakteristično samo za Pulu, već je velik broj društava bio evidentiran na prostoru cijele hrvatske Istre. ${ }^{25} \mathrm{U}$ Puli je potrebno istaknuti Čitaonicu koja je osnovana 1869., Talijansku građansku čitaonicu koja je osnovana 1876., Talijansku radničku čitaonicu Gabinetto operaio di lettura osnovanu 1894., Njemačko čitateljsko društvo Mornarički kasino koje je djelovalo od 1870. do 1918. te društvo Geselliger Lesezirkel osnovano 1910. godine. U Puli je djelovala i Družba sv. Ćirila i Metoda za Istru koja je osnovana 1893., kao i Pjevačko i glazbeno društvo Narodnoga doma u Puli osnovano 1910. ${ }^{26}$

23 Podaci preuzeti iz: Bruno Dobrić, Kultura čitanja i nacionalni pokreti. Čitalačka društva i knjižnice u Puli u drugoj polovici 19. i prooj polovici 20. stoljeća, Pula 2003., 35.

24 Prve doseljenike iz slovenskih krajeva zabilježio je Slaven Bertoša u svojem djelu Život $i$ smrt u Puli. Starosjeditelji i doseljenici od XVII. do početka XIX. stoljeća (Pazin 2002.), gdje je naveo brojne pojedince iz Dekana, Izole, Mareziga, Pirana, Sočerge, Topolovca, Ljubljane, Kopra i drugih krajeva koji su se doseljavali u Pulu već od 17. stoljeća.

25 U Pazinu je djelovao velik broj društava koja su nastala krajem 19. i početkom 20. stoljeća: Hrvatskoslovensko katoličko društvo „Dobrila“, Hrvatsko-slovensko akademsko ferijalno društvo „Istra“, Istarsko planinarsko društvo, Hrvatska glazba, Družba sv. Ćirila i dr. Više o tome u: Mladenka Hammer, „Društveni rad profesora Hrvatske gimnazije u Pazinu (1899.-1918.)“, Hrvatska gimnazija u Pazinu 1899.

- 1999., ur. Josip Šiklić, Pazin 1999., 299-341.

26 Dobrić, Kultura čitanja i nacionalni pokreti, 73. 


\section{Slovenska društva u Puli}

Iako su prva slovenska društva u Istri zabilježena tek krajem 19. stoljeća, doseljavanje je stanovništva iz slovenskih krajeva započelo puno prije. Tako su prvi doseljenici iz slovenskih krajeva zabilježeni već u 17. stoljeću. ${ }^{27}$ Svakako, postoji mogućnost da se doseljavanje iz slovenskih krajeva događalo i ranije, ali to za sada nije potvrđeno. Jednako tako nije potvrđeno ni je li u ranijim razdobljima postojala kakva formalna zajednica slovenskih doseljenika, kako u Puli tako i na prostoru Istre. ${ }^{28}$

Krajem 19. stoljeća osnovano je na istarskom prostoru današnje Republike Hrvatske i prvo društvo, za koje se zasad zna, koje možemo okarakterizirati kao slovensko. Udruženje je nosilo ime Čitaonica, a bilo je osnovano 1886. godine. Osim Slovenaca i Hrvata, tu su se okupljali i pripadnici ostalih slavenskih naroda. U Društvu su djelovali pjevački zbor i tamburaški orkestar. Izričito se pazilo da se govori samo slovenskim ili hrvatskim jezikom. ${ }^{29}$ Podatak o osnivanju Čitaonice zabilježen je u Našoj $\operatorname{slog} i^{30}:$ „,̌́aka braće Slovenacah zasnovala je to družtvo, nek se vidi, da i oni uz ostala družtva ljube svoju domovinu, čeznu za družtvenim životom kao svi ini izobraženi narodi. Zasnovaše oni to družtvo, da pokažu svietu, da se znadu ponosit svojim dičnim imenom, svojim milim jezikom. Da su oni u toj namjeri zasnovali svoje družtvo, da i da braću Hrvate u svoje gnjezdo primu, to je očevidno, pošto družtvo medju svojimi članovi broji takodjer prilično Hrvatah. “31 Druge podatke o načinu djelovanja ili vremenu te razlogu prestanka rada društva nije bilo moguće pronaći.

Iduće društvo osnovano je u Puli 1904. godine. Nosilo je ime Slovensko društvo. Članovi inicijativnoga odbora bili su Fran Krže (vođa Istarske vinarske zadruge u Puli), Ivan Gornik, Andrej Pirc, Ivan Leskovec, Ivan Rant, Anton Filipčič i Matej Pogačnik..$^{32}$ Pravila djelovanja, odnosno Statut

27 Slaven Bertoša, "Doseljenici iz Kopra i njegove okolice u puljskim matičnim knjigama od 1613. do 1817.“, Acta Histriae, 9, 2, 2001., 389-414.

28 Više o doseljavanju stanovništva iz slovenskih krajeva, o njihovom životu i djelovanju vidi u: Barbara Riman, „Doseljavanje slovenskog stanovništva s današnjeg prostora Republike Slovenije u Pulu do 1918. godine“, Razprave in gradivo, 64, 2011., 68-85.

29 Ujčić, Kazališni i kulturno-umjetnički život Pule, 30-31.

30 Naša sloga su prve istarske novine na hrvatskom jeziku. Počele su izlaziti u Trstu 1870. dvaput na tjedan na četiri stranice maloga formata. Prvi je urednik bio Antun Karabaić, svećenik Krčke biskupije, koji je tada djelovao u Trstu, a pomagao mu je Mate Bastian. Krilatica im je bila "Slogom rastu male stvari, a nesloga sve pokvari“, koja je ukazivala na važnost hrvatsko-slovenskoga zajedničkoga političkog nastupanja u Istri. Novine su izlazile u Trstu do 1899., a poslije u Puli. Prestale su izlaziti 25 . svibnja 1915. zbog ratnih zbivanja. Stipan Trogrlić, „Naša sloga“, Istarska enciklopedija, 526-527.

31 „Iz Puljšćine“, Naša sloga, br. 21, 27. 5. 1886., 1.

32 U literaturi su traženi bilo koji biografski podaci o tim osobama koje su djelovale u slovenskim društvima, no ništa nije pronađeno. 
toga društva, potvrđen je 1904. godine. Kao cilj društva navedeno je da žele „...skrbeti za povzdig društvene izobrazbe in gospodarskega stanja članov ter za primerne zabave; podpirati po možnosti siromašne ali ponesrečene člane in sicer do najvišjega zneska k 30.- mesečno; priskrbljevati brezplačne službe.“" ${ }^{33}$ Upravni odbor je imao deset odbornika i tri zamjenika, koji su imali mandat od godinu dana. U pravilima je zabilježen i postupak u slučaju da društvo prestane s djelovanjem. Zapisano je bilo da „Če se društvo razpusti vsled sklepa oblasti, se izroči premoženje društva zadnjem predsedniku, ki ga mora po svoji previdnosti razdeliti v javne dobrodelne namene. “" Iako je društvo prestalo djelovati, u izvorima nismo našli potvrdu o imovini društva ili o tome je li ona dana u dobrotvorne svrhe.

Obavijest o osnivanju toga društva objavljena je i u novinama Naša sloga. Novinar je zabilježio da je osnovano „Slovensko Društvo u Pulju. Pod tim imenom ustanovili su ovdje nekoji mladji Slovenci, poglavito iz Kranjske, za se posebno društvo. Pravila je već potvrdilo namjesničtvo u Trstu.“" ${ }^{\text {“5 }}$ Na osnivačkoj skupštini bile su i istarske javne osobe poput Matka Laginje i Ivana Zuccona. Oni su pozdravili prisutne i, između ostaloga, iznijeli su svoje mišljenje o osnivanju novoga društva. Laginja je naglasio da su se ti Slovenci mogli prikloniti i djelovati u već postojećim slovenskim društvima. To nam ukazuje na brojnost društava koja su na sličan način djelovala u Puli i u Istri u ono vrijeme. ${ }^{36} \mathrm{U}$ Odbor su bili izglasani A. Pirc kao predsjednik, I. Gornik, P. Selina, J. Ojsteršek, A. Meznarčič, I. Rant, A. Gantar, I. Mulc, A. Bratož i I. Leskovec. Za zamjenike su bili izglasani A. Valič, J. Malnič i G. Paval. ${ }^{37}$ Društvo je djelovalo relativno kratko. Detaljnijih podataka o aktivnostima u tiskanim medijima nije bilo moguće pronaći, iako su u pravilima zabilježili da će se „...vse objave in pozivi namenjeni članom (...) razglaševati po časopisih, okrožnicah ali javnih oglasih..." ${ }^{\text {"8 }}$

Kada se govori o članstvu, sigurno je da je u nekom periodu Slovensko društvo brojilo više od 40 članova. Naime, u jednoj od klauzula u Pravilima

33 Archivio di stato di Trieste, I. R.: Luogotenenza del Litorale, Società 1814-1918, b. 15, Pravila društva "Slovensko društvo" v Pulju.

34 Ibidem.

35 „Slovensko Društvo u Pulju“, Naša sloga, br. 19, 11. 5. 1904., 6.

36 „Tada je bilo po državnim zakonima lako osnovati društvo. Trebalo je kotarskoj političkoj oblasti naprije prijaviti ustanovnu skupštinu tri dana unaprijed, a poslije joj poslati pravila. Kada je vlast potvrdila pravila, ili ako se u vrijeme od mjesec dana nije usprotivila, smatralo se to društvo zakonito ustanovljenim. " Božo Milanović, Istra u dvadesetom stoljeću, I, Pazin 1992., 31-32.

37 „Slovensko Društvo u Pulju“, Naša sloga, br. 19, 11. 5. 1904., 6.

38 Archivio di stato di Trieste, I. R: Luogotenenza del Litorale, Società 1814-1918, b. 15, Pravila društva „Slovensko društvo“" v Pulju, 4. 
društva bilo je zapisano: „Društvo se smatra ustanovljeno, kadar pristopi 40 članov sprejetih od pripravljalnega odbora, koji nadomešča društveni odbor dokler se za ne izbere. “99 Janez Kramar navodi da je društvo djelovalo dvije godine. Već travnja 1906. predsjednik društva A. Pirc poslao je dopis da društvo ne može više postojati. ${ }^{40}$ Nije jasno zašto je društvo djelovalo tako kratko i koji su bili razlozi prestanka njegovih aktivnosti. Jedno od objašnjenja kratkotrajnoga djelovanja pojedinih društava je, vrlo vjerojatno, u činjenici da su pokretači i inicijatori društava djelovali u više udruga, često su bili studenti i nisu imali dovoljno vremena aktivnije djelovati u svim društvima, zbog obaveza na studiju, poslu i drugdje. Stoga je zanos djelovanja relativno brzo nestajao pa je dolazilo i do gašenja društva.

Godine 1908. zabilježeno je postojanje Slovenske narodne čitalnice. ${ }^{41}$ Podaci o radu toga društva nisu pronađeni.

Već 1911. djeluje novo društvo pod nazivom Skup Slovencev. Aktivnost društva i djelovanje pojedinačnoga članstva djelomično se može rekonstruirati po podacima iz članaka u Našoj slogi. Podaci o točnom vremenu osnivanja nisu pronađeni, kao ni službena pravila. ${ }^{42}$ Kako je zabava toga društva organizirana već u siječnju 1911., postoji mogućnost da je društvo bilo osnovano i prije, ali da se tim povodom prvi put spominje. Zabava je bila organizirana u Sokolskoj dvorani u Puli. ${ }^{43}$ Zabave i različita druženja članovi društva su organizirali i u idućim mjesecima 1911. i u 1912. godini. Tako su u siječnju organizirali predpusnu zabavu. Nastupala je Glazba C. i kr. pješačke pukovnije br. $87 .{ }^{44} \mathrm{U}$ programu je zabilježeno da je muški zbor otpjevao djela G. Ipavca Mili kraj i V mraku te H. Volariča Vienac slovenskih narodnih pjesama, ${ }^{45}$ što znači da je u društvu djelovao i muški zbor. Dobit je bila namijenjena u korist Družbe sv. Ćirila i Metoda za Istru i

39 Ibidem.

40 Kramar, Narodna prebuja istrskih Slovencev, 353-354.

41 Idem, 380 .

42 Službene podatke o djelovanju toga društva nismo našli u Državnom arhivu u Trstu, gdje su pronađena pravila ostalih slovenskih društava koja su djelovala u Puli do 1918.

43 Osim društva Skup Slovencev, dvoranu za zabavu tih su dana unajmila i Hrvatska čitaonica, Narodna radnička organizacija i Sokol. „Zabave u Sokolskoj dvorani“, Naša sloga, br. 2, 12. 1. 1911., 2.

44 „Raspored zabave je ovaj: 1. D. Jenko: Naprej zastave slave, orkestar; 2. Pozdravni govor; 3. F. Smetana: Predigra i napjevi iz opere »Dalibor«, orkestar; 4. Dr. G. Ipavec: Mili kraj, muški zbor; 5. Tominski: Taka sem laka..., kuplet; 6. Iv. pl. Zajc: Dvopjev iz opere »Zrinjski«, orkestar; 7. Dr. G. Ipavec: V mraku, muški zbor; 8. Tominski: Pupu, kuplet; 9. H. Volarič: Vienac slovenskih narodnih pjesama, muški zbor i orkestar; 10. H. O. Vogrič: Žalovski kuplet iz »Moč uniforme«, kuplet uz pratnju orkestra; 11. Leibold: Hrvatki dom, potpourri, orkestar; 12. Doktor sveznalica i njegov sluga Stipko Tiček, šaljiva igra u 2 čina.“ „Zabava s plesom“, Naša sloga, br. 3, 19. 1. 1911., 1.

45 Ibidem. 
Kranjsku. ${ }^{46} \mathrm{Na}$ zabavi je bilo sakupljeno 80 kruna, koje su predane spomenutoj organizaciji. ${ }^{47}$ Predaja sakupljenih financijskih sredstava bio je uobičajen način djelovanja većine društava onoga vremena. Mnogo je društava nakon organiziranih zabava prikupljena sredstva davalo nekoj organizaciji koja se brinula za obrazovanje, kulturno uzdizanje i širenje nacionalne svijesti na prostoru Istre. Novac se najčešće predavao Družbi sv. Ćirila i Metoda. ${ }^{48}$

U ožujku su članovi društva organizirali još jednu zabavu u dvorani Narodnoga doma pod naslovom Veselica v Postojnski jami. Tada je sakupljeni novac dan za svesokolski slet, koji je bio održan u Zagrebu. ${ }^{49}$ Dvoranu su uredili dekoracijama Hrabroslava Vogriča. Dvorana je izgledala kao da se nalaze u spilji. Organizirano je bilo i natjecanje u ljepoti. ${ }^{50}$

Idući događaj za koji znamo bio je u rujnu 1912. godine. Novinar je zabilježio: „...imali su Slovenci radnici zabavu, spojenu sa berbom, srećolovom, plesom i dr. u restauraciji Cuzzi, koja je bila vrlo dobro posjećena." ${ }^{{ }^{51}}$ Sakupljenih 88,94 kruna poklonili su slovenskoj Družbi. ${ }^{52}$ Ne zna se kada je društvo prestalo s djelovanjem i je li prestalo ili je samo promijenilo ime.

Već 1913. zabilježeno je osnivanje novoga slovenskog društva, kada je pokrenuto Slovensko pevsko, zabavno in podporno društvo v Pulju. ${ }^{53}$ Pravila društva su slična pravilima ostalih slovenskih društava koja su se osnivala u ono vrijeme. Društvo je svoje sjedište imalo u Puli, društveni jezik je bio slovenski. U programu društva je bilo pjevanje, igranje, organiziranje izleta, osnivanje knjižnice, organiziranje predavanja i međusobna pomoć savjetima u gospodarskom, trgovačkom, pravnom ili drugom području. Politika je bila isključena. Dogovoreno je bilo i da će imovina društva, u slučaju da se društvo raziđe, pripasti Družbi sv. Ćirila i Metoda „...in sicer pol istrski in pol

\footnotetext{
46 Ibidem.

47 „Skup Slovenaca“, Naša sloga, br. 4, 26. 1. 1911., 2.

48 Osim Družbi sv. Ćirila i Metoda, donacije su se davale i Đačkom pripomoćnom društvu koje je bilo osnovano u Pazinu. Ideja je djelovanja društva bila stipendiranje onih učenika i studenata koji su dolazili iz najsiromašnijih obitelji. Osim toga, trudilo se sakupiti novac kojim bi se izgradio učenički dom u Pazinu za učenike koji su polazili pazinsku Hrvatsku gimnaziju. Zbog različitih problema, s gradnjom đačkoga doma se započelo tek 1913. godine. Alojz Štoković, „Đačko pripomoćno društvo. Najbitnija udruga pri ustrojavanju Hrvatske gimnazije u Pazinu“, Hrvatska gimnazija u Pazinu 1899. - 1999., 399-412.

49 „Zabava s plesom“, Naša sloga, br. 10, 9. 3. 1911., 2.

50 „Zabava s plesom“, Naša sloga, br. 11, 16. 3. 1911., 5.

51 „Zabava Slovenaca u Puli“, Naša sloga, br. 40, 3. 10. 1912., 2.

52 Autor teksta je dao i svoj komentar na činjenicu da se novac poslalo u Ljubljanu slovenskoj Družbi sv. Cirila in Metoda. Napisao je da i hrvatska Družba sv. Ćirila i Metoda za Istru ima velikih potreba te da je ona, osim hrvatskih škola, u Istri osnovala i tri slovenske škole, koje i financira. Ibidem.

53 Kržišnik-Bukić, „O narodnostnem in kulturnem samoorganiziranju Slovencev“, 140.
} 
kranjski. ${ }^{{ }^{5} 4}$ Pravila su prihvaćena u svibnju 1913. godine. Potpisnici su bili R. Rekar, A. Blaznik, J. Kodelja, F. Hudeček, J. Košak i I. Gornik. ${ }^{55}$ Iz dokumenata je vidljivo da se ime Ivana Gornika ponavlja pri osnivanju slovenskih društava u Puli i da je bio i član slovenskoga društva iz 1904. godine. Tada je bio u Inicijativnom odboru, a kasnije je bio i član Odbora toga društva. Da postoje detaljniji popisi članstva društava, vjerojatno bi i broj istih osoba aktivnih u oba društva bio veći. Stoga nam se nameće zaključak da je rad tih društava, uz neredovito financiranje i nedostatak aktivnih članova, bio opterećen i tadašnjom birokracijom.

Djelovanje je različitih društava u to doba bilo onemogućavano ako prema tadašnjim zahtjevima društvo nije bilo odgovaralo društvenim normama ili nije bila ispunjena neka formalnost. Tako je Slovensko društvo u Rijeci u razdoblju do Prvoga svjetskog rata bilo više puta raspuštano i osnivano, sve dok nisu bile ispunjene zahtijevane formalnosti. ${ }^{56} \mathrm{Zbog}$ toga su društva često imala podjednaka pravila jer su ona u osnivanju preuzimala od postojećih već prihvaćena pravila nastojeći izbjeći birokratske zapreke.

Društvo je svoju prvu zabavu organiziralo 5. listopada 1913. u dvorani Narodnoga doma u Puli. Nakon koncerta bio je organiziran i ples. Nema podataka o tome tko je sve sudjelovao na koncertu i kakav je bio program. ${ }^{57}$ To je ujedno i jedina obavijest o djelovanju toga društva koju smo uspjeli pronaći u tisku i arhivu.

Slovenska društva surađivala su s hrvatskim i drugim slavenskim društvima, u duhu ideja o slavenskom zajedništvu. ${ }^{58}$ Slovenski doseljenici su, kao što je vidljivo, djelovali u vlastitim društvima, u kojima su vrata bila otvorena i drugim Slavenima pa je realno pretpostaviti da su jednako tako Slovenci sudjelovali u aktivnostima društava drugih slavenskih naroda. Poznati i društveno ugledniji doseljenici bili su aktivni u većem broju društava. Zbog velikoga broja slovenskih doseljenika, koji su u Pulu došli iz različitih razloga, Slovenci su do početka Prvoga svjetskog rata izgradili tradiciju slovenskih društava i čitaonica u Puli. Iako su društva uglavnom

\footnotetext{
54 Archivio di stato di Trieste, I. R.: Luogotenenza del Litorale, Presidiali, b. 378, Pravila „Slovenskega pevsko-zabavnega in podpornega društva u Puli“.

55 Ibidem.

56 Barbara Riman, „Slovensko družtvo na Reki u Riečkom novom listu od 1909. do 1913.“, Rijeka, 2, 2007., 29-52.

57 „Koncert sloven. pjevač. društva u Puli“, Naša sloga, br. 41, 9. 10. 1913., 2.

58 U Našoj slogi nalazimo članke koji pozivaju na slavensku solidarnost i zajedničko djelovanje: „Veliki ples za Družbu“, Naša sloga, br. 5, 4. 2. 1911., 2.
} 
kratkotrajno djelovala i nastavljala se jedno na drugo, svejedno su ispunila svoju ulogu očuvavši kod članova slovenski jezik i kulturu.

Ubrzo je započeo Prvi svjetski rat te je u tom razdoblju bilo zabranjeno okupljanje i organiziranje zabava. Velik broj stanovnika južne Istre, osobito žena, djece i staraca, iseljen je u Austriju, Češku i Moravsku. U Puli je uveden policijski sat, a i broj stranica u novinama je smanjen. Dotadašnje obavijesti zamijenjene su novim temama koje su se uglavnom odnosile na ratna zbivanja. List Naša sloga prestao je izlaziti, a zamijenio ga je Hrvatski list koji je izlazio od 1915. do 1918.

Nakon rata nastupile su velike političke promjene, koje su izazvale prekid postojanja slovenskih, ali i svih ostalih kulturnih i inih netalijanskih društava. Neka su društva djelovala ilegalno i stoga njihove aktivnosti nije moguće rekonstruirati, druga su se pak raspala.

Došlo je do uništenja Narodnoga doma u Trstu, gdje je bilo sjedište slovenskih kulturnih i gospodarskih organizacija. Tako je bila uništena kinodvorana, velika knjižnica, sjedište Glazbene matice, hotel Balkan s restoranom, kavana, Slovenska kreditna banka te sjedište sokolskoga, đačkoga i planinarskoga društva. ${ }^{59}$ Godine 1927. bio je donesen zakon o zabrani djelovanja slovenskih društava na prostoru Julijske krajine, kojih je bilo više od 400. U nekoliko mjeseci su sva bila raspuštena, imovina je bila zaplijenjena i najčešće predana Dopolavoru. Na prostoru Istarske pokrajine djelovala su 1927. još 23 društva, koja su bila zatvorena u rujnu iste godine. ${ }^{60}$ Tako je bilo onemogućeno djelovanje slovenskih društava na čitavom prostoru novoosnovane Julijske krajine, pa tako i u Istri.

Do osnivanja slovenskoga društva u Puli nije došlo nakon Drugoga svjetskog rata, iako je postojala velika mogućnost za takvu organizaciju. Potrebno je napomenuti da je nakon Drugoga svjetskog rata došlo do obnove nekih slovenskih društava u mjestima gdje su i ranije bile zabilježene aktivnosti doseljenih Slovenaca. Tako je odmah nakon rata obnovljeno društvo Slovenski dom u Zagrebu, i to već $1945 .{ }^{61}$ U Osijeku je društvo France

59 Lavo Čermelj, Slovenci in Hrvatje pod Italijo med obema vojnama, Ljubljana 1965., 246-253.

60 To su bila sljedeća društva: Djevojačko društvo Učka, Čitaonica Danica, Draga iz Buzeta, Società Filarmonica iz Momjana, Kraška Zora iz Kopra, Società irredentista slava, Galižana, Gorska Vila iz Sluma, Gorska Vila iz Kopra, Sportsko društvo iz Buja, Società culturale iz Poreča, Prosvjeta iz Pazina, Jadran iz Dekana, Hrvatska čitaonica iz Buja, Književno društvo i Žensko društvo iz Sv. Ivana (Buzet), Glazbeno društvo i Gospodarsko društvo iz Sv. Martina (Buzet), Slavnik iz Kozine, Žensko društvo iz Buzeta, Zemljoradnička prosvjeta iz Buzeta, Venež iz Kozine, Zvijezda iz Materije i Jadran iz Hrpelja. Državni arhiv u Pazinu, HR-DAPA-55, Puljski kapetanat, kut. 60, Trattamento gruppi etnici allogeni, 3.

61 Silvin Jerman - Ilinka Todorovski, Slovenski dom v Zagrebu: 1929-1999, Zagreb 1999., 37. 
Rožman osnovano 1946., no djelovalo je samo do $1948 .{ }^{62}$ Do ponovnoga pokušaja osnivanja došlo je 1970., kada je osnovano društvo Stane Sever. U Rijeci je Slovenski dom Kulturno prosvetno društvo Bazovica osnovano 1947.; ${ }^{63}$ vrlo je aktivno te djeluje i danas. U Karlovcu je 1951. obnovljeno/ osnovano Kulturno prosvetno društvo Slovenski dom - Triglav v Karlovcu. ${ }^{64}$

Zbog svega toga moglo se pretpostaviti da će se u Puli nakon Drugoga svjetskog rata također osnovati slovensko društvo. Prema popisu stanovništva, od 1953. do danas u Puli je obitavalo preko 1000 Slovenaca. ${ }^{65}$ Ta brojka govori da su Slovenci konstanta u životu Pule i da je njihov broj bio dovoljno velik da se osnuje udruga. U Puli je živio i određen broj slovenskih intelektualaca, a činjenica je i to da su u javnom životu Pule istupale osobe koje su se doselile iz različitih slovenskih krajeva i koje su imale vrlo velik utjecaj na kulturu i razvitak grada. Štoviše, moglo bi se reći da je djelatnost nekih od njih imala dugoročne posljedice za javni život grada, odnosno, da su se Slovenci nalazili među inicijatorima i aktivistima pretvaranja naglo raseljenoga i potom novim stanovništvom naseljenoga mjesta $u$ istinsko urbano središte. ${ }^{66}$ Pitanje je zbog čega te osobe nisu preuzele inicijativu i eventualno oko sebe okupile istomišljenike koji bi tada bili jezgra za osnivanje, ali i daljnje djelovanje slovenskoga društva. Kao jedan od razloga zašto do osnivanja društva nije došlo nameće nam se i ideja da se u Puli zbog velikoga broja doseljenika iz različitih krajeva nekadašnje Jugoslavije nije osjetila potreba za osnivanjem društva koje bi u svojem imenu imalo nacionalna određenja. Vjerojatno u poslijeratnom zanosu te zbog brojnosti pripadnika različitih nacionalnosti (Srbi, Makedonci, Albanci, Slovenci i dr.), slovenski doseljenici nisu imali potrebu za jačanjem svojega kulturološkog identiteta, već su se identificirali s gradom. Drugi razlog također je vezan za identitet - postoji mogućnost da je regionalni identitet, koji je i danas vrlo jak u hrvatskoj Istri, prevladao nad etničkim identitetom. ${ }^{67}$ Treći je razlog vezan za politiku koja je obilježila razdoblje nakon Drugoga svjetskog rata,

\footnotetext{
62 Idem, 42.

63 Barbara Riman - Kristina Riman, Slovenski dom Kulturno prosvetno društvo Bazovica, Rijeka 2008., 12.

64 Adi Gruden, „V novih pogojih obnavljamo društvo“, Spominska knjiga ob 30-letnici Kulturno prosvetnega društva „Slovenski dom - Triglav“, ur. Adi Gruden, Karlovac 1960., 10.

65 Jakov Gelo, Narodnosni i vjerski sastav stanovništva Hrvatske 1880 - 1991 po naseljima, 4, Zagreb 1998., 2622.

66 U Puli je nakon Drugoga svjetskog rata zabilježeno aktivno djelovanje redatelja Lojze Štandekera, glumice Brede Urbič, glumca Lojze Zupana, fotografa Alojza Orela, Marjana Rotara, turističkoga djelatnika koji je započeo s organiziranjem Pulskoga filmskog festivala, koji djeluje i danas, i mnogih drugih.

67 Medica, „Sodobno organizacijsko povezovanje Slovencev v hrvaški Istri“, 397.
} 
a koja nije bila sklona podržavati osnivanje nacionalnih društava konstitutivnih naroda nekadašnje Jugoslavije izvan prostora njihovih država. Na to ukazuje i djelovanje samo dvaju slovenskih društava na prostoru Hrvatske ${ }^{68}$ u razdoblju nakon Drugoga svjetskog rata. ${ }^{69}$

Situacija pulskih Slovenaca mogla bi se ilustrirati i ovakvim hipotetičkim pitanjem: ako netko s unutrašnjim porivima da se bavi dramskom umjetnošću (ili nekom drugom kulturnom ili umjetničkom djelatnošću) ima priliku sudjelovati u osnivanju i radu kazališta (kao što je Istarsko narodno kazalište), zašto bi umjesto toga osnivao dramsku sekciju i jednakim se poslom bavio amaterski, a za oba ta vida dramske djelatnosti ne može imati ni snage ni vremena. To nam također daje djelomičan odgovor zbog čega nije došlo do formiranja udruženja Slovenaca u Puli.

Na prvu slovensku organizaciju u Puli bilo je potrebno čekati sve do 1994., kada je došlo do formalnoga udruživanja i organiziranja Slovenaca u Puli u kulturno-prosvjetno društvo koje je nazvano Unija Slovencev za Istrsko županijo. Inicijativni odbor je bio ustrojen u Puli, ${ }^{70}$ sastao se 12 . veljače 1994. i pozvao sve zainteresirane Slovence da se uključe u buduće djelovanje novoosnovanoga društva. Kao cilj djelovanja Unija je navela njegovanje kulturne baštine slovenskoga naroda, povezivanje sa Slovenijom, organiziranje gostovanja slovenskih kazališta u Istri te nastupe drugih kulturnih i javnih osoba, što je ujedno trebalo utjecati na obogaćivanje kulturne djelatnosti u Istri. Unija je bila zamišljena kao poveznica Slovenaca u svim istarskim mjestima. Ideja je bila vrlo dobro postavljena, ali Unija nije nikada zaživjela.

Naredni pokušaj formiranja slovenskoga društva u Istri bio je uspješan, o čemu svjedoči već jedanaestogodišnje djelovanje toga društva. Naime, u lipnju 2001. došlo je do organiziranja društva Slovenaca za grad Pulu. Osnovano je Slovensko kulturno društvo Istra, koje je u svojem dosadaš-

68 To su društva koja djeluju i danas: Slovenski dom „Zagreb“i Slovenski dom Kulturno prosvetno društvo „Bazovica“. Iako je bilo pokušaja osnivanja i drugih društava na prostoru Hrvatske za vrijeme nekadašnje Jugoslavije (društvo u Karlovcu i Osijeku), ona su djelovala mali broj godina.

69 Donekle nam tu tezu potvrđuje i činjenica da su do 1954. bila zatvorena sva slovenska školska odjeljenja na prostoru cijele nekadašnje Jugoslavije. Slovensko odjeljenje u Labinu je djelovalo samo 1947., odjeljenje u Rijeci je djelovalo 1950. - 1953., a zatvorena su bila i slovenska odjeljenja koja su djelovala po mjestima u Vojvodini (Gudurica, Velika Greda, Banatsko Plandište). Franc Cevc, „Selitve Slovencev v Vojvodino pred drugo svetovno vojno“, Slovensko izseljenstvo. Zbornik ob 50-letnici Slovenske izseljenske matice, ur. Milica Trebše-Štolfa in Matjaž Klemenčič, Ljubljana 2001., 313-314. Više o djelovanju slovenskoga odjeljka u osnovnoj školi i zalaganju Zore Ausec vidi: B. Riman - K. Riman, Slovenski dom Kulturno prosvetno društvo Bazovica; B. Riman, „Riječka Slovenka Zora Ausec i Slovenci u Rijeci nakon 1945. godine: »bratski narod« ili nacionalna manjina“, u: Drago Roksandić - Ivana Cvijović Javorina (ur.), Intelektualci i rat 1939. - 1947., zbornik radova s međunarodnog skupa Desničini susreti 2012., II, Zagreb: FF press - Filozofski fakultet, 2013., 363-378.

70 J. O., „Inicijativni odbor priprema osnivačku skupštinu“, Glas Istre, 10. 2. 1994., 9. 
njem radu ostavilo značajnoga traga u kulturnom životu grada i cijele Istre, a značajno je i za djelovanje Zveze slovenskih društev na Hrvaškem. ${ }^{71}$

Prva predsjednica Slovenskoga kulturnog društva Istra bila je Alojzija Slivar. ${ }^{72}$ Prve godine djelovanja Društvo nije imalo svoj prostor, dobilo ga je tek 2003. u najam, a otkupilo ga je 2010. uz pomoć slovenske vlade. Nedostatak vlastitih prostorija djelomično je otežao rad Društva u počecima njegova djelovanja i usporilo je njegov rast te utjecalo na početni zanos utemeljitelja i članova Društva.

U Društvu danas djeluje niz sekcija. Najaktivniji je mješoviti pjevački zbor Encijan koji je do sada ostvario niz samostalnih nastupa. Osim nastupa u vlastitim prostorima, zbor često gostuje po Hrvatskoj, ali i izvan njezinih granica. U Hrvatskoj su zabilježena gostovanja u Rijeci, Zagrebu, Poreču i Labinu. U Sloveniji je zbor gostovao kod različitih kulturnih društava, ali je prisutan i na tradicionalnim manifestacijama, kao što su Tabor u Šentvidu pri Stični ili Srečanje v moji deželi. ${ }^{73} \mathrm{U}$ ožujku 2011. zbor je prvi put nastupio na manifestaciji Primorska poje $\mathrm{e}^{74} \mathrm{u}$ Gorici.

U Društvu djeluju i druge sekcije. Jedna od njih je Zdravo življenje, u sklopu koje članovi izmjenjuju savjete o zdravom načinu života, vježbaju, pripremaju stara zaboravljena jela, a često organizirano sakupljaju ljekovite trave.

U Društvu djeluje i Kreativna delavnica, gdje se izrađuju ukrasni predmeti i tako pokušava očuvati tradicionalna kultura krajeva iz kojih su članovi došli, ali i pridonijeti kulturi kraja u kojemu žive. U prostorima Društva organiziraju se izložbe likovnih radova i to uglavnom akademskih slikara i slovenskih autora, a uspostavljena je i uspješna suradnja s Obalnim galerijama iz Pirana. Organiziran je i tečaj slovenskoga jezika, koji financira Ministarstvo za školstvo (Ministrstvo za šolstvo) Republike Slovenije.

Posebno je važno to što su članovi Društva pokrenuli časopis Mavrica koji izlazi četiri puta godišnje. Poznata je motivacijska važnost takvih časo-

71 Zveza slovenskih društev na Hrvaškem je krovna organizacija svih slovenskih društava na prostoru današnje Hrvatske. Njezina je osnovna zadaća ujedinjavanje i povezivanje svih slovenskih društava u Hrvatskoj te oblikovanje zajedničkih stajališta prema Republici Sloveniji i Republici Hrvatskoj. Osnovana je 1992. na inicijativu Vinka Žiberta, koji je ujedno bio i njezin prvi predsjednik. Vinko Žibert, „Slovenci v Reki in na Hrvaškem“, Slovenci v Hrvaški, 401.

72 Natja Jenko Sunčič, „,Rojaki od Kvarnerskega zaliva do juga Istre“, Savaglas, br. 60, 7. 8. $2002 ., 11$.

73 Klavdija Velimirović, „Slovensko kulturno društvo Istra iz Pule“, Moja Slovenija, IX, 2010., 9.

74 Revija zborova se održava svake godine u razdoblju od veljače do travnja u različitim krajevima zapadnoga i južnoga dijela tromeđe Italije, Hrvatske i Slovenije. Manifestacija je započela 1970. i od tada se redovno održava. Godine 2011. sudjelovalo je 209 pjevačkih zborova - mješovitih, ženskih, muških, ruralnih, mladih i crkvenih. M. Ra., „Ovacije za pulski Encijan u Italiji“, Glas Istre, br. 81, 23. 3. $2011 ., 17$. 
pisa za rad pojedinih sekcija, ali i za aktivaciju članstva i pridobivanje novih članova. Uostalom, već samo postojanje takvoga časopisa znak je postojanosti i društvene važnosti nacionalne manjine koja ga ima snage izdavati. Časopis izlazi od 2007. i u njemu su zabilježena sva događanja koja su se odigrala u prostorima društva.

Vrlo važnim događanjem smatra se i organizacija Dneva slovenske kulture, koje Društvo organizira od 2007. ${ }^{75}$ Svake godine Dani slovenske kulture imaju neku određenu tematsku crtu koja se provlači kroz sva događanja u toj manifestaciji. Prve je godine bila obilježena 100. obljetnica dolaska slikara i glazbenika Saše Šantela u Pazinsku gimnaziju. Dnevi su tako postali tradicionalno događanje u Puli u organizaciji Slovenskoga doma. ${ }^{76}$

U Društvu je vrlo važna i izdavačka djelatnost. Tako je početkom 2006. godine izdana knjiga Martina Bizjaka pod naslovom Orel, Štandeker in Rotar v Pulju: moji trïe izabranci iz časa po Drugi svetovni vojni. Druga je knjiga bila zbirka pjesama Barbare Slivar San u oblaku zvijezda, a objavljena je i pjesnička zbirka Damijane Šubic Pezdirc Kraški zvončki. ${ }^{77}$

Valja napomenuti da je u djelovanju Slovenskoga kulturnog društva Istra zabilježena želja za suradnjom s ostalim slovenskim društvima koja djeluju na prostoru Istarske županije. ${ }^{78}$ Upravo su aktivni članovi toga Društva bili u mnogo slučajeva zaslužni za pomoć pri osnivanju novih slovenskih društava na prostoru Istarske županije jer su im davali trajnu podršku. Pri zajedničkom djelovanju važno je navesti njihove zajedničke proslave Slovenskoga kulturnog praznika. ${ }^{79}$ Osim toga, vidljiva je i snažna međusobna potpora članova slovenskih društava prilikom svakoga značajnijeg događaja u životu određenoga društva.

Na temelju ovoga kratkog pregleda djelovanja Slovenskoga kulturnog društva Istra u Puli, može se zaključiti da je njegova djelatnost vrlo široka i članovi vrlo aktivni. Danas je u Društvo učlanjeno oko 400 članova, dok ih je 2002. bilo 200. Poput ostalih slovenskih društava u Hrvatskoj, ima pot-

75 Velimirović, „Slovensko kulturno društvo Istra iz Pule“, 9.

76 Eadem, „Dnevi slovenske kulture v Pulju“, Novi odmev, 32, 2007., 13; eadem, „Dnevi slovenske kulture v Pulju“, Novi odmev, 35, 2008., 12.

77 Eadem, „Društvo Istra: založniška dejavnost“, Novi odmev, 30, 2006., 11.

78 U Istarskoj županiji djeluju i slovenska društva Društvo Slovencev Labin (od 2006.), Slovensko kulturno društvo Oljka iz Poreča (2008.), Slovensko kulturno društvo Lipa iz Buzeta (2008.) i Slovensko kulturno društvo Ajda iz Umaga (2011.).

79 Klavdija Velimirović, „Slovenci v Istri skupaj praznovali Prešernov dan“, Novi odmev, 34, 2008., 12; eadem, „Slovenci v Istri skupaj praznovali kulturni praznik“, Novi odmev, 37, 2009., 14; Jasmina Ilić Draković, „Sporočilo iz Pulja: kultura je pamet“, Novi odmev, 40, 2010., 10. 
poru nadležnih slovenskih i hrvatskih institucija. Svojim djelovanjem okuplja Slovence koji žive u Puli, ali i druge građane, te približava Puljanima kulturu susjednoga naroda. Tako dodatno razvija dobrosusjedske donose i, općenito, senzibilizira javnost za problem manjina. Razumijevanje za svoje aktivnosti i rad članovi Društva pronalaze i u Gradu Puli i u Istarskoj županiji jer je istarski poluotok, zbog svoje bogate i karakteristične povijesti, tolerantno okružje.

\section{Zaključne misli}

Kada se promatra cjelovita povijest slovenskih društava u Istri, tada je moguće zaključiti sljedeće: značajke djelovanja pulskih slovenskih društava u svakom pojedinom razdoblju vidljive su i kod drugih slovenskih društava toga vremena na prostorima današnje Republike Hrvatske. Između nekadašnjih i sadašnjih društava postoje razlike, ali i sličnosti.

Zbog maloga broja arhivskih izvora teško je detaljnije govoriti o aktivnostima slovenskih društava s kraja 19. i početka 20. stoljeća. Nedvojbeno je da su ta društva imala drugačije zadaće i ciljeve nego današnja. Ona osnivana krajem 19. i početkom 20. stoljeća u središtu svoga djelovanja imala su podupiruće aktivnosti: osim očuvanja jezika i kulture prostora s kojega su članovi društva došli, na prvom je mjestu bilo osiguravanje materijalne i moralne pomoći za sunarodnjake. Kulturna dimenzija je u tim prvim društvima bila u drugom planu i tu je moguće povući paralelu s drugim društvima osnivanima u ono vrijeme. Slični su procesi zabilježeni i u kvarnerskim društvima s početka 20. stoljeća.

Popis članova, pogotovo kada se radi o starijim društvima, nije moguće izraditi, ali iz onih malobrojnih zabilježenih imena vidljivo je da su djelovanje tih društava podupirali, između ostalih, i značajni istarski preporoditelji, političari i intelektualci. Uočljivo je i da je određen broj članova bio aktivan u različitim društvima. Dakle, kada bi postojali popisi članova (ovdje iznesena imena su imena članova koji su se svojim radom isticali, odnosno bili su pokretači tih društava), vjerojatno bi se podudarao veći broj imena na popisima više društava.

Starijim društvima teže je bilo institucionalizirati svoje djelovanje i očuvati ga, što se može zaključiti iz činjenice da sva slovenska društva koja su nastajala krajem 19. i početkom 20. stoljeća nisu bila dugovječna niti su bilježila kontinuirani rast. Jednako je bilo i sa slovenskim društvima koja su 
djelovala u Opatiji, Rijeci, Karlovcu i Zagrebu. Podataka o tim društvima nema mnogo, a na to je utjecao kratak period djelovanja, u kojem nisu mogla razviti svoje aktivnosti do one razine do koje to mogu današnja društava koja djeluju duže vrijeme. Razloga je za to bilo mnogo. Već sama nacionalna klima, koja je u Istri bila specifična, onemogućavala je rad slovenskih društava. Društva nisu imala svoje prostore i često su se članovi nalazili u restauracijama/kavanama/gostionicama, koje su najčešće imale slovenske vlasnike. Aktivnosti društava nije moguće prikazati kronološki i u potpunosti. Ne možemo znati jesu li ona djelovala redovito ili su u svojim djelovanjima imala stanke. Možda su se članovi sakupljali samo povremeno, kada je bila kakva zabava ili nekakav drugi događaj.

Još jedan razlog kratkotrajnoga djelovanja društva može se tražiti i u pokretačkoj sili koja je osnivala društva. Obično su to bili studenti, intelektualci, koji su u Puli boravili kraće vrijeme te ih je put i posao (studij) prisiljavao na često mijenjanje mjesta boravka. Drugi je razlog činjenica da su oni često bili aktivni i u drugim društvima te su uz posao imali malo vremena aktivnije se i trajnije uključiti u djelovanje svih društava kojima su bili članovi. Na to ukazuje i relativno velik broj društava koja su djelovala $u$ Puli, ali i na prostoru cijele Istre.

Novinski članci, koji su nam u proučavanju starijih društava bili osnovni izvor, pisani su isključivo hrvatskim jezikom, što nije bio slučaj sa slovenskim društvima u Rijeci i Opatiji. Članci o njihovom djelovanju, kao i obavijesti članstvu, bili su pisani slovenskim jezikom.

Različita su društvena, politička i gospodarska povijesna događanja utjecala na djelovanje slovenskih društava, ali ona u tome nisu bila izolirana, već su ih pogađala kao i druga kulturna, umjetnička, amaterska, sportska i ina društva u Istri. To je osobito uočljivo u razdoblju nakon Prvoga svjetskog rata, kada na istarskom poluotoku nije zabilježeno djelovanje ni jednoga slovenskog društva. Osnivanje slovenskih društava nakon Drugoga svjetskog rata događalo se diljem cijele nekadašnje Jugoslavije, osim na prostoru današnje Istarske županije. To možemo pripisati jakoj identifikaciji doseljenoga stanovništva s gradom, odnosno jakom osjećaju regionalne pripadnosti. Konačno je 1994. došlo do prvoga pokušaja formiranja udruge pripadnika tada već priznate slovenske manjine na prostoru Republike Hrvatske, ali je tek 2001. ostvareno uspješno pokretanje slovenskoga kulturnog društva. Slovensko društvo koje i danas djeluje u Puli ima samo 
kulturnu dimenziju, poput ostalih slovenskih društava nastalih nakon osamostaljenja dviju država.

Današnja društva uglavnom imaju prostore (unajmljene, rjeđe vlastite), imaju stalnu financijsku (relativno) stabilnu pomoć, a u svojem djelovanju prvenstveno se temelje na kulturnim aspektima očuvanja jezika i kulture. Pri njihovom djelovanju vidljiv je kontinuitet i rast društva s obzirom na broj aktivnih i potpornih članova, ali i s obzirom na intenzitet rada različitih sekcija koje djeluju u društvu.

Kod svih slovenskih društava, koja su kroz prošlost djelovala u Puli, zamijećeno je povezivanje s kulturnim društvima iz iste sredine. Kod suvremenih se društava vidi i potreba za suradnjom s ostalim slovenskim društvima na prostoru Republike Hrvatske, kao i s onima na prostoru Republike Slovenije. Te se veze ostvaruju i zbog napredne tehnologije kojom današnja društva raspolažu (vrlo dobre prometne veze, telefonija, internet itd.). Je li postojala veza između starih slovenskih društava u Puli sa slovenskim društvima onoga vremena u drugim gradovima, može se samo nagađati. Kod ovdje promatranih društava vidljiva je i njihova uloga u svakodnevnom kulturnom životu Pule. Organiziranjem zabava, koncerata, a u današnje vrijeme i većih kulturnih događaja, ostavila su zamjetna traga u kulturnom životu grada.

U daljnjim istraživanjima bilo bi potrebno evidentirati i važne pojedince iz redova slovenske manjine u vremenima kada nisu bila aktivna slovenska društva u Puli, kroz čije bi se živote i djelovanje moglo još bolje valorizirati važnost slovenskih doseljenika, kao i drugih koji su osobnim radom pridonijeli današnjoj slici urbanoga života Pule, odnosno kvaliteti života grada u vremenima za koje se zna da i nisu uvijek bila povoljna ni za pojedince, ni za određene društvene skupine.

\section{Sažetak}

Članak prikazuje osnivanje i djelovanje slovenskih društava u Puli od kraja 80-ih godina 19. stoljeća do danas. Na temelju prikupljenih arhivskih izvora i druge građe prikazano je osnivanje društava, kao i djelovanje njihovih članova. Uz to, prikazan je i prestanak rada nekih slovenskih društava koja su djelovala u Puli. Osim prikaza njihova rada, u članku se otvaraju pitanja vezana za važnost društava, kao i za procese i razloge njihova nastanka koji su usko povezani s društveno-političkim događanjima, osobito razlozi njihova gašenja. U radu su upotrijebljene različite znanstvene metode i to historijska metoda, metoda analize, metoda sinteze, metoda kompara- 
cije i generalizacije. Iz kronološkoga prikaza djelovanja slovenskih društava u Puli može se zaključiti da su se ona u određenim povijesnim razdobljima zalagala za različite vrijednosti koje su u tom trenutku njihovim članovima bile u prvom planu. U samom početku, društva su prije svega označavala mjesto gdje su doseljeni pojedinci mogli dobiti određenu sigurnost te materijalnu i duhovnu potporu, a kulturno je djelovanje bilo sekundarna djelatnost. To je egzistencijalna dimenzija koja se pojavljuje pri svim slovenskim društvima koja su djelovala na prostoru današnje Republike Hrvatske sve do kraja Drugoga svjetskog rata. U novije je vrijeme dimenzija djelovanja slovenskih društava u potpunosti kulturna. Djelovanje društva kroz povijest značajno je utjecalo na očuvanje slovenstva u Puli, ali jednako tako ti su doseljenici kao članovi slovenskih društava utjecali i na kulturni život grada, kao i na zbližavanje i bolje poznavanje dvaju susjednih naroda.

La sala di lettura è stata fondata da "una manciata di fratelli Sloveni" con il desiderio "di mostrare al mondo, di andare fieri del proprio orgoglioso nome, della propria cara lingua": le società slovene a Pola dal 1886 al 2011

\section{Riassunto}

L'articolo illustra la fondazione e l'attività delle società slovene a Pola dalla fine degli anni ' 80 del XIX secolo ad oggi. In base alle fonti archivistiche e ad altro materiale raccolto, è stata attentamente presentata la fondazione e l'attività delle società in questione. Sono stati esposti inoltre alcuni aspetti legati alla cessazione delle attività di alcune delle società slovene presenti a Pola. Accanto alla presentazione delle loro attività, il contributo pone alcune domande sull'importanza di questi sodalizi, sui processi e sui motivi della loro fondazione, prettamente legati alle circostanze socio-politiche. Il contributo si avvale di varie metodologie scientifiche tra cui il metodo storico, il metodo dell'analisi, il metodo della sintesi, il metodo della comparazione e della generalizzazione. Dalla presentazione cronologica dell'attività delle società slovene a Pola, è possibile concludere che fecero da portatrici dei valori particolarmente cari ai loro membri. Agli inizi, le società rappresentavano innanzitutto un luogo dove i singoli potevano trovare un appoggio materiale e spirituale, mentre l'attività culturale rappresentava un'attività secondaria. Questa dimensione esistenziale è presente presso tutte le società slovene attive sul territorio dell'odierna Repubblica di Croazia fino alla fine della Seconda guerra mondiale. Negli ultimi tempi, l'attività delle società slovene è prettamente culturale ed ha notevolmente influito sulla preservazione della componente nazionale slovena a Pola che ha sicuramente determinato in maniera non secondaria la vita culturale della città.

The Reading Room was founded by "a handful of Slovenian brethren" in a desire "to show the world, that they are proud of their most dignified name, of their beloved tongue": Slovenian societies in Pula 1886-2011

\section{Summary}

The article presents the founding and the activities of Slovenian societies of Pula from the late 1880's until today. Based on data gathered in the archive and other 
places, the founding of the societies, as well as the activities of their members, has been presented. Furthermore, the discontinuation has been presented of some Slovenian societies who were active in Pula. Not only their activities were shown; the article unfolds some of the questions which talk of the importance of societies, as well as the processes and the reasons behind creation of societies which were entangled with socially-political events, this especially goes for the reason for their discontinuation. The article uses different scientific methods: historiography method, analysis method, method of synthesizing, comparative method and generalization. From the chronological overview of the Slovenian societies of Pula, one can deduce that at certain points in time they advocated different values which were a priority for their members at the time. Societies were, at the very beginning, first of all a place for the newcomers to gain certain security as well as material and spiritual support; the culture was only a secondary aspect. This existentialist dimension occurs within every Slovenian society which were active on the territory of Republic of Croatia up until the end of Second World War. In the recent times the activities of Slovenian societies are solely cultural. The activities of the societies throughout history have been the keeper of "Slovenianism" in Pula, but also, those settlers, as members of Slovenian societies, have had an impact on the culture of the city, as well as acquainting and bonding the two neighbourly nations. 
